\title{
SZKIC CHRYSTOLOGII KLEMENSA ALEKSANDRYJSKIEGO W ŚWIETLE ONOMASTYKI PIERWSZEJ KSIEGI „PEDAGOGA”
}

Pragnąoy zapoznać sie z chrystologlą Klemensa Aleksandryjskiogo znajdzie na interesujący go temat szereg artykułów 1 monografi1, wóród których na czoło wysuwaja sie prace P.B.Pade'a, " $\Lambda$ p Untersuchungen zur Logos - Christologie des Titus Flavius Clemens von Alexandrien" 1 E.Faschera, "Der Logos - Christus als gottlicher Lehrer bei Clemens von Alexandrieñ ${ }^{3}$. Autorzy obu rozpraw wykazuja, zo Idea wodaca 1 centrum całej chrystologil klemensa jest 1dea Logosu, który 1stniejąc jako druga osoba Boska, Jako Syn Boga Odw1ecznogo zstapiz na ziemie $i$ objawił sie w ciele jako Jezus Chrystus*. Tonze Logos jest Stwórcą, Nauczycielem 1 Wychowawcą ${ }^{5}$. Z prac tych korzystał niewątpliwie w swym podreczniku J.Quasten przy omawianiu teologil Klemensa Aleksandryjsklego, gdzle stwierdziz, ze zbudowal on system teologiczny biorąc za punkt wyjścia 1 fundament całej swej nauk1 ideg logosu' ${ }^{6}$. Pojęole to zdominowało wodług Quastena oaja toologie Klemensa 1 całe jego myślente. Podkreśla, zo Logos jest Zbawicielem, Stworzycielen nowogo życia; Chrystus jako Logos Vicielony jost Bogiem 1 człowiekiem. Na koniec jeszcze raz powtarza, ze idea Logosu stanowi centrum systemu teologlcznego klemensa 1 ksztartuje cała jego myśl religljną ${ }^{7}$. W relacji Quastona logocontryzm Klomensa

1 The Christology of Clement of Alexandria, "Journal of Theological Studies" 5/1904/ 123-136; R.P.Casey, Clement and the Two Divine Logo1, "Journal of Theological Studies" 25/1923/43-56; M.Pellegrino, La catechesi cristologica di S.Clemente Alessandrino, Milano 1940; A.Brontes1, La soteria in Clemente Alessandrino, Roma 1972, 297-340.

2 Rom 1939.

3 Studion zum Neuen Testament und zur Patristik /TU 77/, Berlin 1961, 193-207.

4 P.B.rado, dz.cyt. 173.

5 B. Feascher, dz.cyt. 207.

6 J.Quasten, Patrology, vol. II, Utrecht 1953, 21-23 /mThe Doctrine of the Logos"/.

7 J.Quasten, dz.cyt. 23: "Thus the idea of the Logos is the centro of Clement's thoological systom and of all his religlous thinking". 
Aleksandryjsklego nie podlega dyskusjl, jest oczywisty 1 totalny.

iytrawn1 czytelnicy Klemensa bez trudu zorientuja sie, zo oplnta ta, najdelikatniej móviac, jest mocno przerysowana, bazujaca na zbyt katwym uproszczeniu. Obraz chrystologi1 xlemensa jest - wiele bogatszy 1 bardziej złozony, choć w ramach niniejszego artykułu njelatwo będzto to udowodnić. Spróbujmy jednak to uozynić, oblerajac nowsza netod $Q$ badań nad Klemensem, która proforuje śledzente typowych dla obranoj problematyk1 torminón wo wazystkich jego dziołach ${ }^{8}$. Ze wzgl ̨du na szczuplość ram niniojszogo opracowania ograniczono sle wyłacznie do plerwszej ksiegl "Podagoga". W dziele tym przośledzono mszystkie określenia rzeczownikowo 1 przymiotnikowe odnoszace sie do osoby Chrystusa, majac na uwadze $1 \mathrm{ch}$ rodzaj 1 częstotliwość występowania.

1. Onomastyka chrystologiczna I ks1eg1 "Pedagoga"

a/ Określenta rzeczownikowe ${ }^{9}$

\begin{tabular}{|c|c|c|c|c|}
\hline Lp. & Tormin grecki & Znaczonio & Ilość & Miejsce \\
\hline 1. $\Lambda \sigma \gamma \circ r_{2}$ & $/ J 1,1 /$ & Skowo & 127 & $\begin{array}{l}1,1 ; 1,2 \\
/ 2 x / ; 1,3^{10}\end{array}$ \\
\hline 2. Yv́nloc & /wt $8,2 /$ & Pan & 105 & $\begin{array}{l}7,1 ; 8,2 ; 9 \\
41\end{array}$ \\
\hline
\end{tabular}

8 To metode badań obrali przy pisantu swych prao o Klomensio: A.Brontesi, La soteria in Clemonte Alessandrino, Roma 1972; M.Berciano, Kalros. Tyempo humano historioo-salvifico on Clemente de Alejandxia, Surgos 1976; F.Draczkowsk1, Kośció Agape według Klemensa Áleksandryjskiego, Lublin 1983.

9 Przez okroślonia rzoczownikowe rozumiemy rzaczonntk1, przymiotniki w funkcji rzeczownikowej oraz imlestowy przymiotnikowe w funkoj1 rzoczownikowej.

10 c.d. $/ 2 \mathrm{x} / ; \quad 1,4 ; 2,1 / 2 \mathrm{x} / ; 3,3 / 2 \mathrm{x} / ; 4,1 ; 5,2 ; 6,1 / 2 \mathrm{x} / \mathrm{i}, 6,2$; 8,$2 ; 9,3 ; 9,4 / 2 x / ;$ w tytule rozdz. IV; 13,$2 ; 14 ; 5 ; 15,3 / 2 \mathrm{x} /$; 17,$1 ; 23,2 ; 24,4 ; 25,1 ; 25,2 ; 25,3 ; 31,1 ; 31,2 ; 33,2 ; 33,3$; 35,$3 ; 36,1 / 2 x / ; 36,5 ; 37,3 ; 40,2 ; 41,3 ; 42,1 ; 42,2 ; 42,3 ; 43,2$ $/ 2 x / ; 43,3 / 3 x / ; 43,4 ; 45,2 ; 46,1 ; 47,2 ; 47,3 / 3 x / ; 47,4 / 3 x / ;$ 49,$3 ; 49,4 ; 50,4 ; 51,1 / 2 x / ; 53,3 / 2 x / 557,1 ; 57,3 ; 58,1 ; 58,2$; 
Lp. Jiermin grock1

3. $\Pi \alpha\llcorner\delta \alpha \gamma(\omega) \gamma \delta$

4. $\mathrm{X} \cap\llcorner\sigma \tau \delta c$

sit 1,1/

Chrystus

Syn

5. Ylbc

/LAk 1,11/

Wychowawca

Ilość

Miejsce
6. Inoods sit 1,16/ Jozus

7. $\theta \varepsilon \sigma s$ /J 1,1/ Bog

8. Поцнरи /J 10,11/

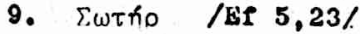

Pasterz

Zbavca
23

72

spis tresci: I, 1I, III ${ }^{12}$

15,$2 ; 18,2 ; 18,3^{13}$

4,$1 ; 12,5 ; 20,2$ $/\left.2 x\right|^{14}$

22

12,$3 ; 16,1 ; 23$, $2^{15}$

16

$4,1 / 2 x / ; 7,1$ $/\left.2 x\right|^{16}$

11

37,$3 ; 52,2 / 2 x / 17$

6,$3 ; 27,3 ; 43,1^{18}$

$59.1 / 2 x / 59,2 ; 60,1 / 2 x / ; 60,2 / 2 x / ; 61,1 ; 62,3 / 2 x / ; 62,4$; 63,$1 ; 63,3 ; 65,3 ; 66,5 ; 67,3 ; 69,2 ; 69,3 ; 71,3 ; 72,2 ; 74,4 ; 75,1$; 82,$3 ; 84,1 ; 89,1 / 2 x / ; 91,3 ; 93,2$; w tytule rozdz. XI; 96,1 ; 96,$3 ; 97,1 ; 97,2 ; 98,3 ; 99,1 / 2 x / ; 100,1 ;$ w tytule rozdz. XIII; $101,1 / 7 x / ; 101,2 / 3 x / ; 101,3 ; 102,1 ; 102,2 ; 102,4$.

11 c.d. 10,$1 ; 11,2 ; 12,2 ; 12,4 ; 12,5 ; 13,2 ; 14,4 ; 16,1 ; 17,3 ; 18,1 ;$ 18,$2 ; 20,1 ; 23,1 / 4 x / ; 23,2 / 3 x / ; 24,1 ; 25,2 ; 26,1 ; 28,2 ; 28,5 ;$ 31,$2 ; 36,1 ; 36,5 ; 37,2 ; 37,3 ; 38,2 ; 38,3 ; 41,3 ; 42,2 / 2 x / ; 42,3$; 43,$2 ; 43,3 / 2 x / ; 44,1 ; 45,4 ; 47,1 ; 47,2 / 2 x / ; 49,2 ; 49,4 ; 50,1 ;$ 52,$1 ; 56,2 ; 57,2 ; 57,4 ; 58,1 ; 58,2 ; 59,3 ; 60,3 ; 61,2 / 2 x / 62,1$ $/ 2 x / ; 62,3 ; 66,2 ; 66,4 ; 67,2 ; 68,2 ; 68,3 ; 69,3 ; 70,1 ; 71,1 ; 72,2$; $73,1 / 3 x / ; 75,2 ; 75,3 ; 77,1 / 2 x / ; 77,3 / 2 x / ; 77,4 / 2 x / ; 78,1 ;$ 78,$2 ; 78,4 / 2 x / ; 80,1 ; 81,3 ; 83,1 ; 83,3 ; 84,4 ; 35,2 ; 90,1 ; 90,2$; 91,$1 ; 91,2 ; 91,4 ; 93,1 / 2 x / ; 94,3 ; 95,2 ; 97,3 ; 98,3$.

12 c.d. IV, VII, XII; w tytule rozdz. I; $1,4 / 2 x / ; 2,1 ; 1,1 ; 5,1$; 5,$2 ; 6,1 ; 6,2 ;$ tytulo rozdz. III; 8,$3 ; 9,1$; wytulo rozdz. IV; 10,$2 ; 31,1 ; 32,2 ; 42,3 ; 51,3 ; 53,2 ; 53,3 ; 54,2 ; 54,3 ; 55,2 / 2 x /$; 56,$1 ; 56,2 ; 56,3 ; 56,4 ; 57,1 ; 57,3 / 2 x / 58,1 ; 59,2 ; 60,2 / 2 x /$; 60,$3 ; 61,2 ; 61,3 ; 62,2 ; 66,2 ; 68,1 ; 74,3 ; 75,1 ; 76,1 ; 78,1 ; 81,1$; 83,$3 ; 84,1 / 2 \times / ; 84,3 ; 85,1 ; 87,2 ; 89,3 ; 90,1 ; 92,2 ; 97,1$; $97,2 / 2 x /$; tytul rozdz. XII; 98,$1 ; 98,3 ; 100,2 ; 100,3 / 2 \mathrm{x} /$.

$130.4 .18,4 / 2 x / ; 19,2 ; 20,2 ; 21,4 ; 22,2 ; 23,1 ; 25,2 ; 27,1 ; 30,3$; $31,1 / 4 x / 32,4 ; 34,2 / 2 x / ; 34,5 ; 35,1 ; 35,2 ; 35,3 / 2 x / ; 36,2$ $/ 2 x / 3 \quad 37,2 ; 40,2 ; 41,3 ; 43,1 ; 46,1 / 2 x / ; 49,3 ; 49,4 ; 52,2 / 2 x / ;$ 53,$1 ; 60,1 ; 70,2 ; 73,2 ; 90,2 ; 97,1 ; 98,1 ; 98,3 ; 98,4 ; 99,2 ; 102,4$.

14 c.d. 24,$1 ; 24,4 ; 25,2 ; 28,5 ; 29,1 ; 33,4 ; 53,1 / 2 x / ; 60,3 ; 71,3$; $73,1 / 2 x / ; 74,1 / 2 x / ; 88,2 / 2 x / ; 97,2 / 2 x /$.

$15 \mathrm{c.d}, 31,1 / 2 x / ; 32,2 ; 39,1 ; 43,3 ; 52,2 ; 53,2 ; 35,2 ; 60,1 ; 60,2 ;$ $60,3 / 2 x / 771,3 ; 72,2 ; 73,2 / 2 x / 783,3 ; 97,2 ; 98,1$.

$16{ }_{62,4 ;}^{24}{ }_{97}^{2} ; 24,3 / 2 z / 25,2 ; 55,2 / 2 x / ; 56,2 / 2 x / ; 57,2 ;$ o7, 3; 
Lp. Tormin gracki

10. latsion /Nt 2,8/

Znaczenie

Ilość

Niejsce

11. Tonon

12. Kกเtí,

$/ 2 \mathrm{I}_{\mathrm{m}}$ 4,8/ Sędz1a

13. Alsiourioc Ast $8,19 /$ Nauczyc1el

14. "ALU\%

Krev

15. Avห์́n

$/ 2$ Kor 11,1/ Mazz

16. esoln /EP 4,12/

G owa

17."Aryelor /Iz 9,5/

18. $\Gamma\{\lambda r$

19."intor. /J 6,35/

20. KeAnrewin

21. Hyeuin /Nt 2,6;

N1 $5,1 /$

22. Intoós /Nt 9,12/

23. $\operatorname{son}(\pi / 1$ Kor 1,24$)$

24. Booldeir /Mt 27,11;

Zach 9,9/

25. $i n \pi \iota 06$

26. Гхит́́ /Iz 9,5/

27:Auvós rov acoo $/ \mathrm{J} 1,29 /$

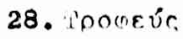

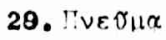

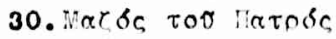

31. Iinyń /Ap 21,6/

32. Ka.Anrovievoc

33. Anusounyóc,

$/ \mathrm{Hbr} 11,10 /$

34. $\Delta \varepsilon \sigma \pi \sigma \tau \eta s / A p 6,10 /$ Wradca
Zw1astun

Mloko

Chlob

Kiorown1k

Proewodnik

Lekarz

Nquiró́ó

Król

N1enowl

ojcioo

Baranek Bozy

$2 y+10101$

Duch

Pleré ojca

Zródzo

Przowodnik

Stwórca
$24,1 / 2 x / ; 24,2^{19}$

41,$3 ; 43,20$

7

4,$2 ; 58,2 / 2 x /$;

67,$3 ; 86,1$

4

3,$3 ; 25,2 ; 32,2$;

58,1

$4 \quad 47,2 ; 47,3 ; 47,4$ $\mid 2 x /$

$3 \quad 18,1 ; 18,2 ; 18,4$

$3 \quad 18,4 / 2 x / ; 22,3$

324,$1 ; 50,1 / 2 x /$

342,$1 ; 45,2 ; 47,2$

$3 \quad 46,2 / 2 \times / ; 47,2$

$3 \quad 1,1 ; 55,2 ; 58,1$

$2 \quad 1,3 ; 65,3$

$2 \quad 6,1 ; 6,2$

$2 \quad 6,2 ; 97,3$

215,$2 ; 22,3$

$2 \quad 24,2 ; 24,4$

$2 \quad 24,2 ; 42,3$

$2 \quad 24,4 / 2 x /$

$2 \quad 42,3 ; 43,3$

$243,3 / 2 x /$

$243,4 / 2 x /$

245,$2 ; 83,3$

$2 \quad-53,2 ; 83,3$

$2 \quad 74,1 ; 97,3$

284,$3 ; 84,4$

17 c.d. 53,$2 ; 53,3 ; 83,3 ; 84,1 / 2 x / ; 84,2 ; 85,2 ; 97,3$.

18 c.d. 83,$2 ; 83,3 ; 98,3 ; 100,1$.

19 c.d. $24,3 / 2 x / ; 24,4 ; 52,1$.

20 c.d. 43,$3 ; 45,2 ; 46,1 ; 47,2 ; 99,1$. 
Lp. Term1n greck1

Znaczenie

Ilość

M1ejece

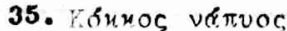

36. $\Delta \iota$ Łиоvоd $\mathrm{Rz} 15,8 /$

37. Elutiv /2 Kor 4,4/

38. ' $\mathrm{A} \pi \cos \delta \mathrm{c}$

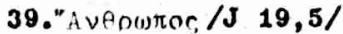

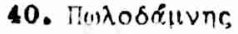

11. Novbueous

42. IEpetov

43. $\Sigma ช \mu$ Rov $\lambda O c$

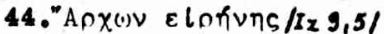

45. Кผ. /uk 1,42/

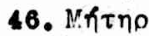

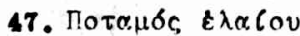

48. Вp(1) $\mu \alpha$.

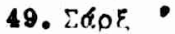

50. Mहै $\lambda_{l}$

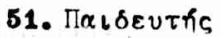

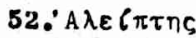

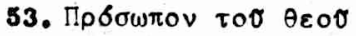

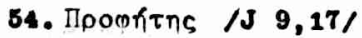

55. $\Sigma . \tau \rho \alpha \tau \eta \gamma \delta \varsigma$

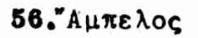

/J $15,1 /$

57. Nikxa เ

tin

58. $\Phi \omega \tau \alpha \gamma \omega \gamma \tilde{r} \sigma \omega \nu$

59. Zwi /J 11,25/

60." A $\lambda \omega \alpha$ /Ap 1,8/

61. $\Omega$ /Ap $2,8 /$

62. TEXOC /Ap 21,6/

63. $b$ है $\tau$ Ta $\prod \alpha \tau \rho l$ $/ J 14,10 /$

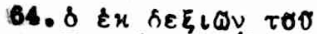

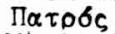
Nt $22,44 /$

Siedzaoy po

/P\& 109,1; prawioy 0joa

Matka

Strumień oleju

Poźywiente

Ciazo

Liód

Wychowawca

Trener

Obliczo boga

Prorok

Dowódca

Krzew winny

M10cz

Osw 1 ecajqcy

aroge

Żyo10

Alfa

umega

Kres

Ten, który jest w 1

ojcu

Siedzaoy po
prawloy ojoa

Pobudzajaoy
86,$1 ; 86,2$

4,1

4,2

6,1

$7,1 / 2 x /$

15,3

17,1

23,1

24,2

24,2

41,3

42,3

45,2

47,2

47,2

51,1

53,3

57,1

57,2

60,3

65,3

66.4

66,5

183,3

183,3

136,1

136,1

136,1

4,1

$1.4,1$

1

1,3 


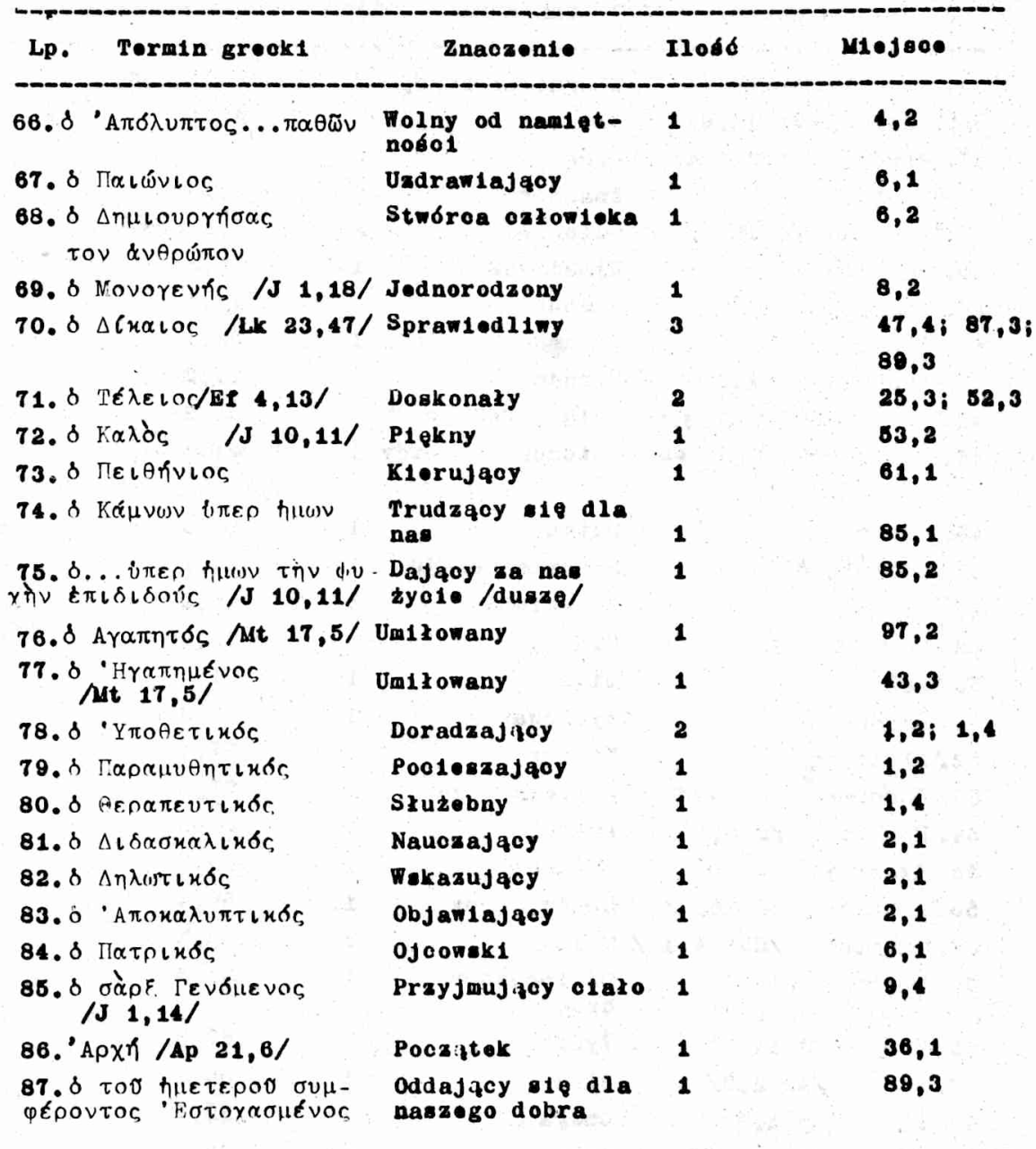

b/ Okresienia praymiotnikowe

Lp. Termin greok1 Znaozenie Ilod́d Miejeoe

$\begin{array}{ll}\text { 1. } 2 \gamma \alpha \theta \delta c, \quad \text { dobry } & 64,3 ; 66,2 ; 10,2 ; 14,1 ; \\ & 85,1 ; 85,2 ; 97,2 ; 97,3 ; \\ & 98,3\end{array}$




\begin{tabular}{|c|c|c|c|}
\hline Lp. Tormin grecki & Znaczenie & loś & Milejsco \\
\hline 2. Sixxlos & sprawiedliwy & 9 & $\begin{array}{l}17,2 ; 47,4 / 2 x / ; \\
71,3 ; 74,1 ; 87,3 ; \\
89,1 ; 89,3 ; 97,2\end{array}$ \\
\hline 3. $\oplus \iota \lambda\{\nu A \cap(1) \pi \cap c$ & $\begin{array}{l}\text { kochajacy } \\
\text { człoricka }\end{array}$ & 6 & $\begin{array}{l}55,2 ; 58,2 ; 63,1 \\
/ 2 x / ; 64,3 ; 85,2\end{array}$ \\
\hline 4. $\theta \varepsilon t O G$ & boski & 5 & $\begin{array}{l}75,1 ; 81,1 ; 97,3 ; \\
100,2 ; 15,3\end{array}$ \\
\hline 5. $\tau \varepsilon \hat{\lambda \varepsilon\llcorner O C}$ & doskonały & 4 & $25,3 / 3 x / ; 24,3$ \\
\hline 6. $\pi \alpha \cdot \tau \rho \iota \kappa \delta c$ & ojcowsk1 & 3 & 6,$1 ; 84,1 ; 97,3$ \\
\hline 7. \&Y̧los & sw 1 q̨ty & 3 & 6,$1 ; 42,1 ; 55,2$ \\
\hline 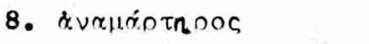 & bezgrzeszny & 2 & 4,$1 ; 4,2$ \\
\hline 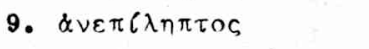 & bez zarzutu & 2 & 4,$1 ; 62,2$ \\
\hline 10. $\sigma(t) \hat{f} \rho \iota \mathrm{oc}$ & zbarczy & 2 & 60,$3 ; 74,2$ \\
\hline 11. $\alpha \lambda \eta \mu_{\iota} \vee \sigma c$ & prawdz1iwy & 2 & 66,$4 ; 37,2$ \\
\hline 12. $\delta \rho A G c$ & prawy & 2 & $\begin{array}{l}\text { w tytula rozdz. XIII; } \\
101,1\end{array}$ \\
\hline 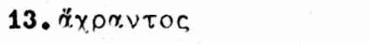 & nieskalany & 1 & 4,1 \\
\hline 14. $2 \pi \pi x A n G$ & nterzruszony & 1 & 4,1 \\
\hline 15. $\& \pi \circ \lambda \mho \pi \tau$ os $\pi \alpha \theta \tilde{\omega} \nu$ & $\begin{array}{l}\text { wolny od namięt- } \\
\text { nośc1 }\end{array}$ & 1 & 4,2 \\
\hline 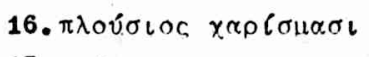 & bogaty rask1 & 1 & 0,4 \\
\hline 17. $\pi \rho \approx \circ c$ & tagodny & 1 & 15,2 \\
\hline 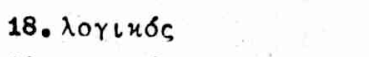 & rozunny & 1 & 29,5 \\
\hline 19. $\chi \rho \eta \sigma \tau \delta \zeta$ & zacny & 1 & 44,1 \\
\hline 20. TOEDOVTOG & karmiacy & 1 & 51,3 \\
\hline 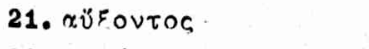 & dający wzrost & 1 & 51,3 \\
\hline 22. ตOTlr, Ovtos & ośw lecajacy & 1 & 51,3 \\
\hline 23. $\mu \alpha \lambda \delta c$ & p1ękny & 1 & 53,2 \\
\hline 24. $x \eta \delta \varepsilon \mu \circ \vee \iota x \delta \varsigma$ & troskl1wy & 1 & 53,2 \\
\hline 25. $\mu \nu \sigma \tau \iota x \sigma_{s}$ & mistyczny & 1 & 59.1 \\
\hline 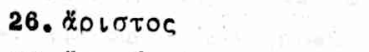 & najlepszy & 1 & 62,2 \\
\hline 27. है & Jeden Jedyny & 1 & 74,1 \\
\hline 28. $\pi \alpha \nu \alpha \gamma \downarrow$ ○द & naj św 1 \& tgzy & 1 & 84,1 \\
\hline 29. $\pi \alpha \nu \tau \circ \mu \rho \& \tau(1) \varsigma$ & wszechmoony & 1 & 84,1 \\
\hline 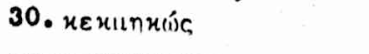 & zmączony & 1 & 85,1 \\
\hline
\end{tabular}




\begin{tabular}{|c|c|c|c|}
\hline Lp. Tormin greok 1 & Znaczenie & Ilośc & Miejsco \\
\hline 31. $\mu \varepsilon \gamma \alpha \lambda$ Brinons & hojny & 1 & 85,2 \\
\hline 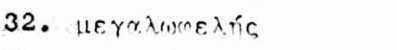 & wielce pozyteczny & 1 & 85,2 \\
\hline 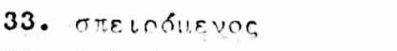 & płodny & 1 & 96,1 \\
\hline 34. is $x+5 c$ & prawdzdwy & 1 & 87,1 \\
\hline 35. $\check{\varepsilon v}$ & Jeden & 1 & 97,2 \\
\hline 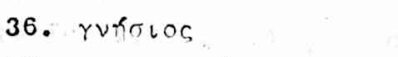 & praivy & 1 & 87,2 \\
\hline 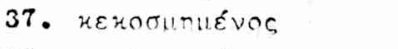 & przyozdobiony & 1 & 97,3 \\
\hline 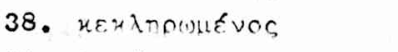 & przeznaczony & 1 & 99,1 \\
\hline 39. suvóarns & mocny & 1 & 24,2 \\
\hline 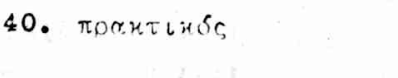 & $\begin{array}{l}\text { praktyczny } \\
\text { /energiczny/ }\end{array}$ & 1 & 2,1 \\
\hline 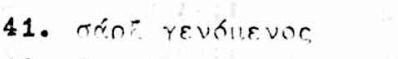 & przyjmujicy c1ało & 1 & 9,4 \\
\hline 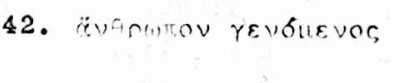 & $\begin{array}{l}\text { przyjmujacy } \\
\text { czlowieczenstwo }\end{array}$ & 1 & 24,4 \\
\hline 43. $\ddot{n} \pi l$ oc & $\operatorname{mity}$ & 1 & 37,3 \\
\hline 44. ¿'ve แusvor & dolikatny & 1 & 37,3 \\
\hline 45. तUveสtorhukvor, & stały & 1 & 37,3 \\
\hline 46. oiprivinc & niebiański & 1 & 1,3 \\
\hline 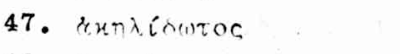 & bez skazy & 1. & 4,2 \\
\hline 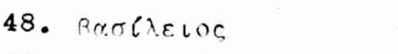 & królewskl & 1 & 22,3 \\
\hline 49. Arvurritós & wspaniazy & 1 & 24,2 \\
\hline 50. x.lí) ᄂoc & odwleczny & 1 & 24,2 \\
\hline 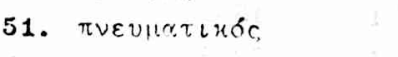 & duchowy & 1 & 41,3 \\
\hline 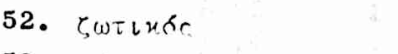 & źyciodajny & 1 & 83,3 \\
\hline 53. $\mu \varepsilon \gamma \alpha c$ & wlelki & 1 & 65,3 \\
\hline
\end{tabular}

\section{Sto cztordziésol imfon Chrystuaa Boga Zbawlajacogo}

Przedstawiony $w$ poprzednim paragrafie materiaz skłania do wielu refleksji 1 wniosków. Plerwsza ksiega "Pedagoga", jak wiadomo, stanow1 zaledwie czastke dorobku plsarskiego Klemensa z Alek- 
sandri1. W tym nievielkim dziole, 110zscyn w walaniu 0.StAnlina zaledwie 63 strony tekstu ${ }^{21}$, zgromadzil autor przobogaty materiat dodycz̨cy nomenklatury chrystologicznej. Jeśl1 potraktowac zącznie okresienla rzeczownjkowe 1 przymotrikowe, to na pytanie kim jest Chrystus moźna udzielić 140 różnych, wzajemnie uzupełniającyoh się, poprawnych odpowiedz1. Klemens pragnił, $\nabla$ miare nozliwośc1, ukazać całe bogactio 1 róźnorodność treśc1, coch 1 funkcj1, jakio łaczy się z Bogiem - Człowiekiem, Jezusem Chrystusem. Ten szerok1 rachlarz róznych nazw $i$ określeń, dzięi któryn otrzyoujemy "portret Chrystusa" wielowymiarowy 1 wieloaspoktowy, nie wyczerpuje bynajmniej calej onomastyki chrystologicznej. If trakcio narracji autor nasz, w uniesieniu i jakby w euforil stwierdza, że Chrystus waściwie jest wszystkim. Sąd ten portórzyz tez dwukrotnie w pierwszej ksiz̨dze "Pe-

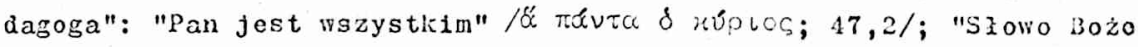

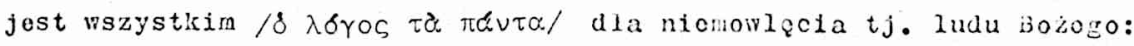
ojccm, matka, wychorawca $i$ jywlcielen" $/ 12,3 /$.

By nie pogublé siţ w tyin labiryncie imion, nazw i okresilen, spróbujuy uporzizdicować ten niezrykie bograty materiał w oparciu o jakąś ideg wiodącą. Fibrow sugestion ne pocziktku cytowanych autorón, taka lintaz riodącą, czy oslá, wokóz której beuzio wozna ustawié wszystkie określenia, będzie nie ldea Logosu, lecz idea Boga Zbariciela. Observacje nasze potwierdzają nowsze balanla A.Bronteslego, który w swej obszernej, wyżoj cytowanej monografil "La soteria in Clemente Alessandrino" stwierdza, zo ddea zbawienia jest głórna i naczelna zasadą całej twórczości klemensa. Wyraz "zbawiente". / ournplo/ jest terminem streszezającym cała Bozą pedagogle 1 wszystk1e wysłłki człowieka dazzącogo do zbawienia ${ }^{22}$.

21 Clemons Alexandrinus, Bd.I: Protropt1cus und Paedagogus, ed. 0. Stthlin, Leipzig GCS 12, 89-152.

22 A.Brontesi, dz.oyt.,597: "qual é il posto della soteria nel Corpus Clementino? $\dot{e}$ un ruolo notivante, al punto che se fosso tolta la salvezza, 11 Corpus non sarebbe scritto. ... Sovente infatti soteria ò 11 tormine riassuntivo di tut ta la pedagogia divina $\theta$ di tutto lo sforzo anagogico dell'uomo". Por. Tamż, 1781424 . 
Nalezy przy tyio dodać, to terwin "zbawienie" / owtmola/ w wykadzie Klenensa wa bardzo szeroki zakres znaczoniowy. If głównej mierze zbawienie - to proces upodobnianta sie do $30 a^{23}$, roalizowany przez cało zycle człowleka dizżzcego poprzez poszczególne etapy hierarchil doskonałości ${ }^{24}$. Lbawiente jest procesem, który ciagle trwa, jest stakya rybawlaniem czkowioka zo wszystkich nieszczesć, w Jaitch on tkwi 1 w jakie ciagle popada. proces ten realizuje 818 poprzez dzlałante zbarcze chrystusa 1 wspósdzlałante człowieka ${ }^{25}$. Caly rodzaj ludzkt potrzebuje stale tak rozumianego zbawienta: "Słusznie zater, chorzy, potrzebujemy znawiciela, bładzacy - Przewodnika, ślepi - Dawcy światła, łaknący - Zródła zyciodajnego, z którego p1jąc nigdy nie będziemy odczuwać pragnienia, umarli - Zycia, owce Pasterza, dzleci - Wychowawcy, a cała ludzka natura - Jezusa, abyómy pozbawien1 przewodnika 1 grzeszn1, nie zostall w końou skazani na potępienie, lecz, oddzielent od plow, złozend zostali w spichrzu ojcowskim" 26 .

IV powyżzym cytacie punktoin wyjócla jest okresienie róznych nleszczęśc, w które człowiek popadł lub stanu nlewystarczalnośc1, jak1 cechuje ezłowicka z sanej jego natury. Chorzy, bładzący, ólop1, umarl1, to c1, którzy popadil in nieszczquele 1 potrzebuja kogoś, kto by 1ch wyrral z tego stunu. Chrystus mybawia choryoh - z choroby, ślepych - wyrywa z lch ślepoty, umarłych wybawia ze śmiero1, błądzących - z błgau. Druga grupa to c1, którzy sa niosamodziolnd, którzy potrzebuja ponocy kogoś druglego dla realizacjl celu swego zycia. Do tej grupy naleźa dzleci, które potrzebuja rodzloó, wyohowawców 1 opjekunów, owce, które potrzebuja pasterza. Nalezacy do toj grupy saz z natury słabi, bezbronnl, niesamodzielni. Chrystus jest

23 Tamżo 601: "perché fondamentalmente salvezza é Imitazione di D10, ...".

24 F.Drączkowsk1, Kośctóz - Agapo według Klemensar Aloksandryjskiogo, Lublin 1983, 64,74,81.

25 A.Brontes1, dz.cyt. $258,310,21,601$.

26 Pedagog I 83,3. Wazystkio teksty z I ka1ęg1 "Pedagogan oytuje w przekładzio ks. Tadeusza Putona: Pedagog - Ksigga I Klomensa Aleksandryjskiego. Wstep, tzumaczenie, komentarz, Lublin 1977 /mps BKUL, Fil.Klas. in. 181/113. 
dla nich Zbawiclelem, ponlewaz pomagu im w osiagnięciu życia, które On sam juz posiada z ojcem 1 Duchem Swiętyn, prowadzuc ich do zbanienia. Dla obu grup Chrystus jest Zbawicielem.

Syntetycznie mozna ujać kondycje ludu Bożego w sześciu katogorlach: unarl1, chorzy/grzeszn1/, głodn1, dziec1, bladzizcy /owce/. ślep1. Chrystus ratuje swój lud z każej operaoj1 1 słaboścl. Odpowiedź na pytanio, kim jest Chrystus zbawiciel, mozna rórniez ująć - sześciu głównych punktach. Relacje te beda przedstariały sie nastepuj izco:

Lud Bozy

Chrystus

\begin{tabular}{|c|c|c|}
\hline $\mathbf{I}$ & Umar 11 & Bбg - życ1e prawdziwe \\
\hline II & Chorzy /grzeszni/ & Boski Lekarz \\
\hline III & Grodn1 & Pokarn Rycia \\
\hline IV & $\mathrm{Dz1} 10 \mathrm{Cl}$ & Bosk1 Wychowawca \\
\hline $\mathbf{v}$ & Błądzący /once/ & Pasterz, lizadca, Przeroodnik \\
\hline VI & Slopi. & Swiatio, Nauczyciel \\
\hline
\end{tabular}

Ad I: Chrystus Bog- zyc10 prawdzi- 0. Jedynie prandziwe zycie jest w Bogu. "Nie znać Boga - to nio tyó, a znać 1 obcowaó a N1m, m1zować Go 1 upodabniać sle do Niego to jedynie jest zyo10n27. Bbg zostak okrosilony Jako Niłość - Agape 28 , ta zaś najkrócej definiuje sie jako "wspólnota życia"29. Bóg w1ęc jest zyciem, jest wspólnota zycia 0jca, Syna i Ducha Swiętego.

W I ksiedze "Pedagoga" na plerwszym planie akcentowane jost Bóstro Chrystusa, który określany jest jalio:

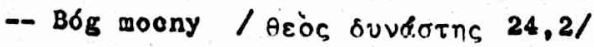

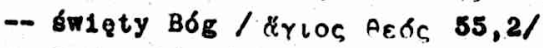

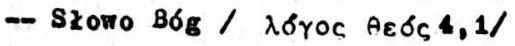

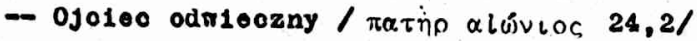

27 Clemens Aleksandrinue, Quis dives salvetur 7,3, tzum. J.Czuj, Jak1 bogacz zostanio mbaw1 ony, Warezawa 1953, 9.

28 I J 4,16; por. Clemens Alekrandrinue, Stromateis /oytuje: Strom/ IV 100,$5 ; 113,4 ; V 13,1$.

29 Strom II 87,2; por. F.Drqozkowak1, Koß́016z - Agapo, dz.oyt., 69-90. 


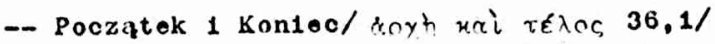

-- Alfa 1 Omega / Kina xai (i) $36,1 /$

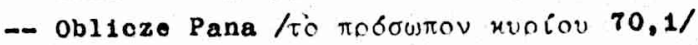

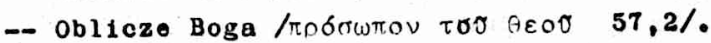

Chrystus jest Boglem, druga osoba Trojoy éw., Synem ojea Przedw1eoznego. Ten lakt, ze Chrystus jest Synem znajduje wyraz wastepujaeych okresieniach:

-- Syn Boga/tor Peos ul6s 24,4/

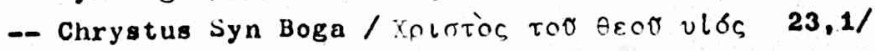

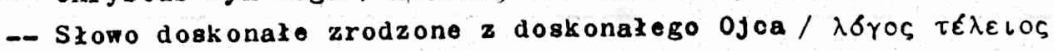

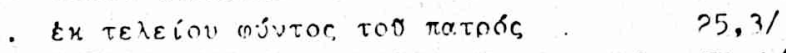

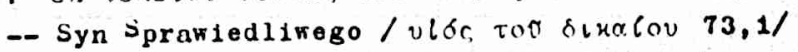

-- Syn Stwórcy / vló tor onแloupyoo 73,1/

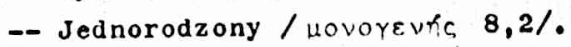

Klemens nie poprzestaje na stwierdzeniu, zo Chrystue jest Bogiem 1 synem. W swej nomenklaturze ohrystologloznej umaględnia określon1a, które oznaczaja relacje: Syn - 0jc1eo. Bosk1e Słowo jest okreslane Jako:

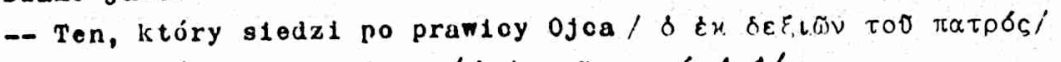

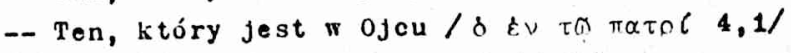

-- Syn w ojcu/ilóc \&v $\pi r$ rol $24,3 /$.

Jako Bóg prawdziny jest zyciem, jest jedynym źódzon 1 danoa zycia prawdziwego. St tiqd określany jako:

-- Życio kin? $83,3 /$

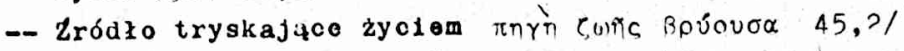

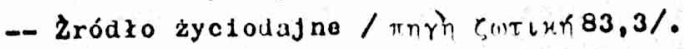

Bóg zapragniaz siroje zycio przekazaó ozłowlekow1, poniewaz kocha

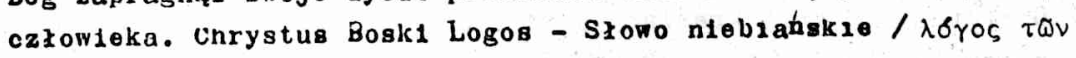
ovpxutiv $16,1 /$

okreslany jest jako:

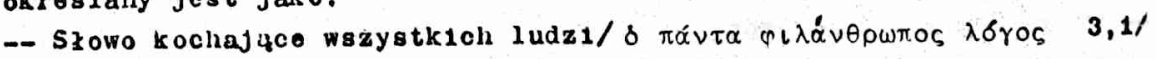

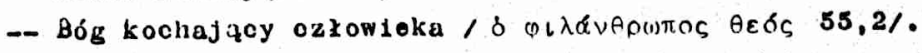

By dać ozłowlekowl zyoie, sam staz sie ozlowiekiem, przyjaz ludzkq nature z Maryl Dzlewicy. Stad okresiany jest jako:

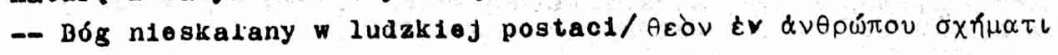
¿̈xpavtos $4,1 /$ 


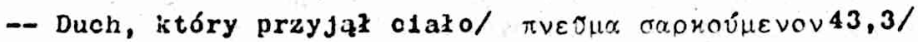

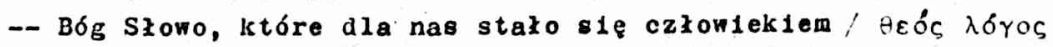

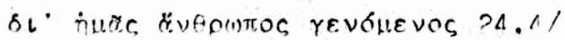

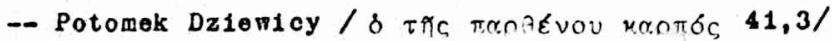

-- Syn Dawida / $\delta$ vló, $\Delta \alpha \delta i \delta$ 12,5/.

By nam wysłuzyé dostęp do życia clerpiał, stał sie Barankiem Bozym złozonym w ofxerze. Stąd określany jako:

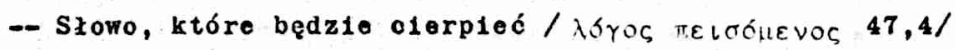

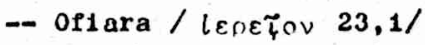

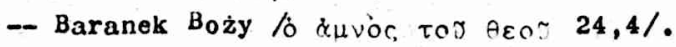

Przez mękę 1 śmierć na krzyzu Chrystus nysłuzył nam dostęp do zycia prawdziwego. Przez obnycie noda chrztu właczył nas do tego zycla, które ma $z$ 0jcem 1 Duchein Sriętym. Jest on wlęc:

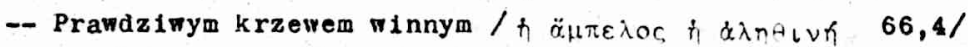

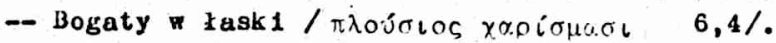
Ad II:
C $\boldsymbol{h}$ r y 8 s $t$ u 8
B 0 s $k 1$
L. $\mathrm{k}$ a $\mathrm{r} z$.

if terminologil 0jcón Kościoła grzech jest choroba duszy. Chorzy sa c1, którzy sa uwikłani wzło. Chrystus jalso Bóg całkowicie wolny jest od zła 1 wszelkiego grzechu; jest święty 1 dostonały, obreślany jako:

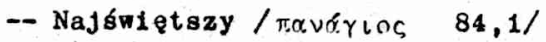

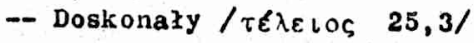

- Swiety /arlos $6,1 /$

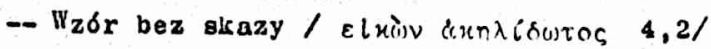

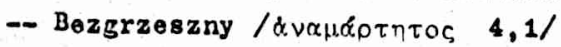

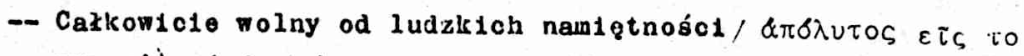

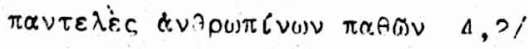

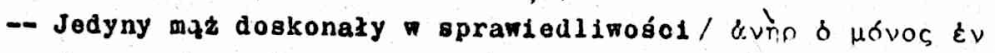

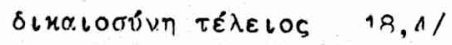

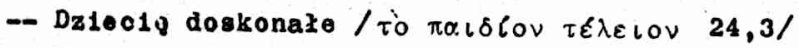

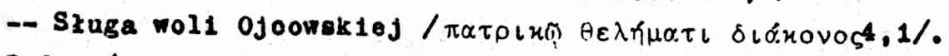

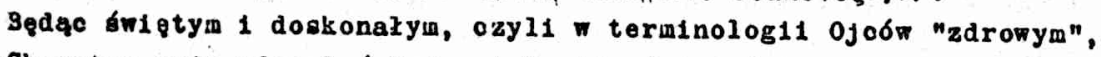
Chryntus moze udzielać "zdrowia", tJ. śwlętości 1 doskonałośol innym. Tak jak byz jodynym źródzeis zyo1a jako Bóg, tak tez jest jedynym źródłem św1ętośo1 1 jedynym lekarzem zdolnym uleozyé od zła. Stą̆ okréslany jest jako: 
-- Jedyny lekarz ludzkich chorób moralnych / แS

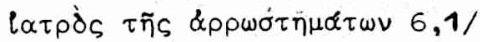

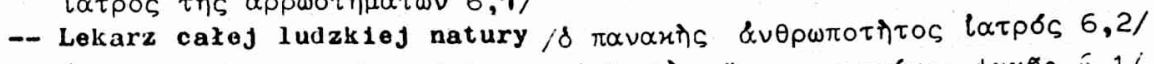

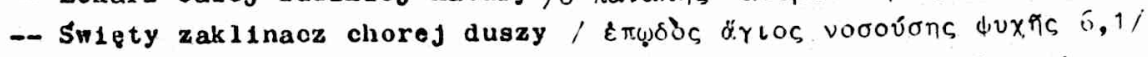

Chrystus jest lekarzem, który obcina to, co niepotrzebne 1 martwe. "Nio podcinany szczep winny zbyt bujnio wyrasta w drzewo; tak toz 1 ezłowleis". Słowo, któr jost Meczem / $\mu^{\prime} \mu \alpha x \alpha \iota \rho \alpha 66,5 /$, obcina nadmlernie wybujałe pędy, zmuszajac naturalne skłonnośct "do prizynoszenla ow ocu" $/ 66,4-5 /$. Słото Bóg jest równiez lekarstwem, poniewaz gol rany grzechowe. Dlatego określany jest jako:

-- Strunień oleju / Totalios Exalov 45,2/.

Ad III: Chry t u P o k a m z y. 0 a Boski Zbawiclel jest jedynym pokarmen, który zdolny jest zaspoko16 wazelki głód człowieka. Karral lud Bozy róznorakim pokarmem. Dlatego określany jest jako:

-- Lywiclel luju młodego /dosłownte: zywiciel dzlecka, któryn jest

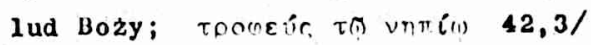

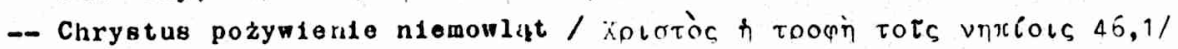

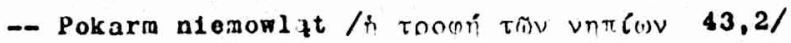

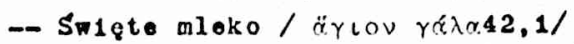

- Pokarm duchowy ludz1 dojrzakych /

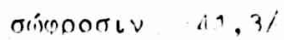

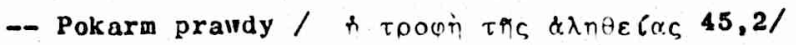

- Chlob niebian /r̈ntoc oúnavinv 46,2/

- Chlob Boga / źntor, too feod 46,2/

-- Pozyriente /Ronua 47,2/

- Ciazo / $\alpha \dot{\rho} \rho, 47,2 /$

- Krow / $\alpha i \mu c, 47,4 /$

- Ni6d / $\mu \varepsilon \lambda_{\iota} 51,1 /$.

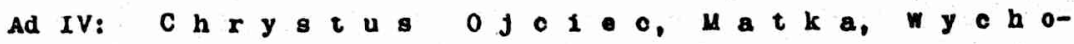
r a c a, T $r$, $\bullet r$. Lud bozy okresla klemens jako: lud wybrany, Iud swiety, lud mzody, I ud nowy, plokleta Pana, mzode trebak1, niemonleta, synowie, disiec1, dzieci Boze. symbolem ludu vozego jest dziecko, kt6re potrzebuje opiek1 1 pomocy ze strony rodzicow 1 wyoliowawo 6 . Uhrystus zaspokaja wszyetk1e potrzeby ludu nowego, czyld dzleoka. Nlatego okrélany jest przez klomensa jako: 


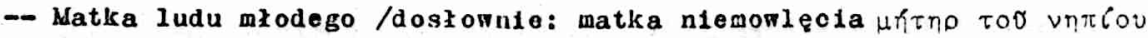
$42,3 /$

-- Ojclec ludu młodego /dosłownie: ojciec niemowlęcla ratìo too vn$\pi i ́$ บ $42,3 /$

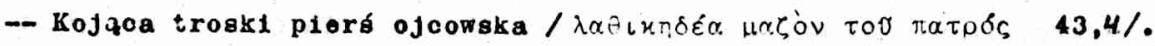
Jest czuxy, dobry, troskliwy 1 wyrozumiały jak rodzice. Stad nos 1 określenta:

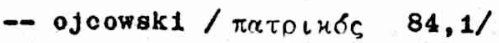

-- doiry / \&yaebc $74,1 /$

- Zagodny / $\pi \rho \%$ \& $15,2 /$

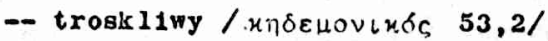

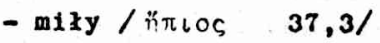

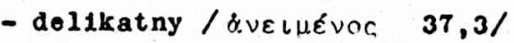

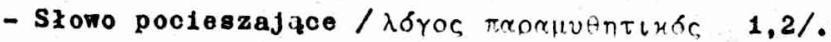

Chrystus jest wychowawca wazystk1ch ludz1 wymlarze uniwersalnym hlstorycznym 1 geograficznym. Jako Bóg jest wychowawca doskonalym. Stąd określenia:

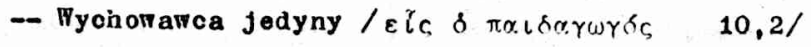

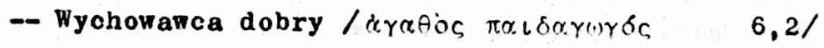

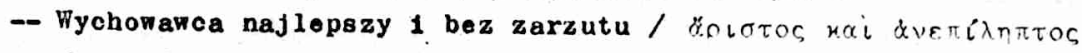
$\varepsilon \sigma \tau \iota \nu \& \pi \alpha \iota \delta \alpha \gamma(1) \gamma \delta c, 6 ?, ? /$

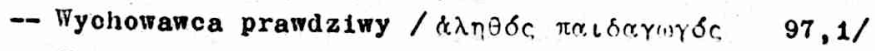

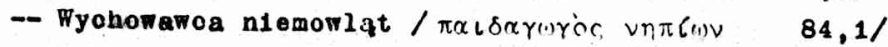

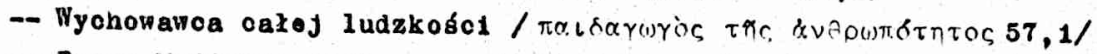

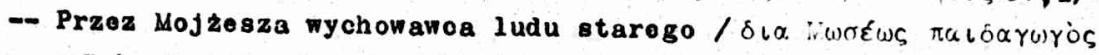

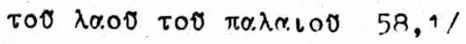

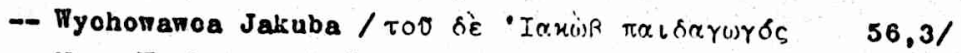

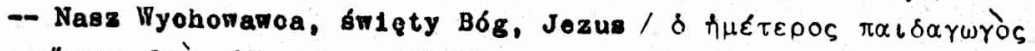

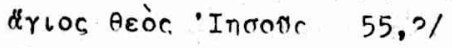

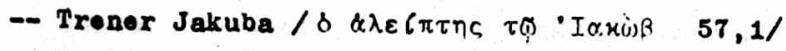

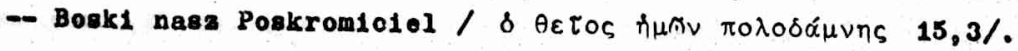

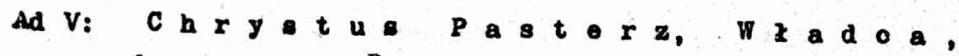
P r o 0 d n $1 \mathrm{k}$. Lud Bozy określony jest czesto przez klomensa Jako owazarnia, której Jedynym pasterzem jest Bosk1 Zbawiolel. Jako Bóg, Chryatus jest doskonazym Pasterzem, który wyprowadaa awoje owce a bzednej drogi na droge wzad́cima; mybaw1a je od zatracenia. Funkoje 
te obrazuja określenta:

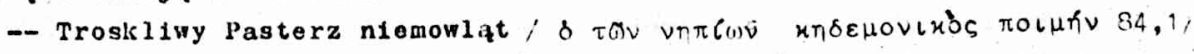

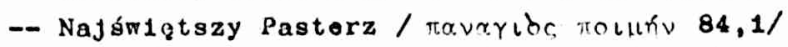

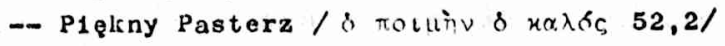

-- Dobry Pasterz $/ \&$ kycidc noukn 37,$3 ; 97,38$ por. J 10,11/.

Pasterz, troszczac sie o owce, prowadzac jo na wasciva droge, jest zarazom loh przowodnik1em. Chrystus Dobry Pasterz jest przewodnikiem 1 wodzem, który swoje dzlooi, lud Boży 1 caza ludzkośó prowadzi do zbarienia. $Z$ togo tytułu określany jest jako:

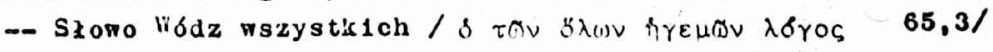

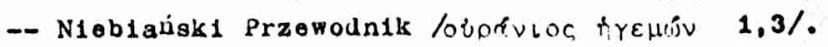

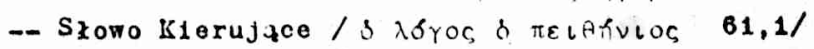

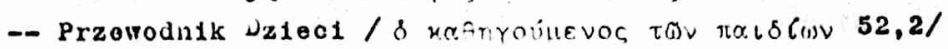

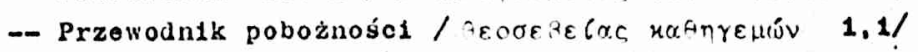

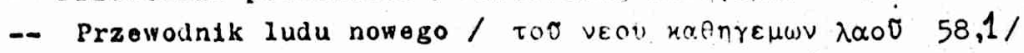

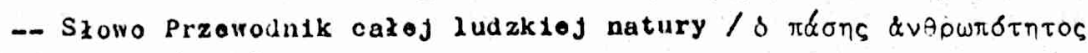

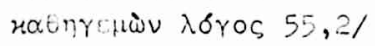

Jako pasterz Bosk1 Zbawiciol jest nie tyllo przerodnikiam, ale 1 wadca owczarni - ludu Bozego. Posiada władze ustawodawoza 1 sadonniczq. Falst ten obrazuja nastepujace okresienia:

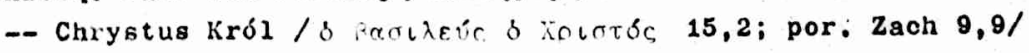

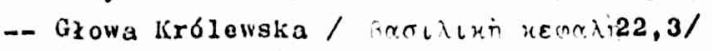

-- Głowa / uemriti 18,4; por. Ee 4,12, 22,3/

- Wadca / seorítrg 84,3-4/

- Sędzia / unctio 4,2/

- Ksiaże pokoju / äny(u) Einriver 24,2; por. Iz 9,5/

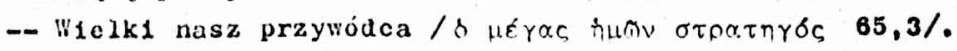

Ad VI: Chry t u s S w 1 a t $10-N$ a u 0 z y 01.1 "Cleminość" jest czesto synonimen błędu 1 nlewiedzy, Jak "órtatłośc" jest symbolem prawdy 1 mizdrosci. Boskio Skowo, uosobiona Maqdośd jest Ĺródłom wszolkiej prawdy i jedynym jej Nauczyolelem. Wybawia swój Iud z ciennośc1 1 bżdu prowadzac go ku zbawozej prawda1e. Te tuncoje obrazuja nastęujace okresienta chrystusa:

- Mzarość / $\operatorname{co\varphi }[\alpha, 6,2 /$

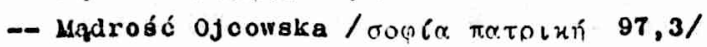

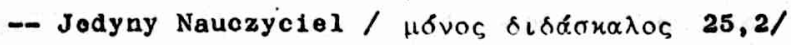

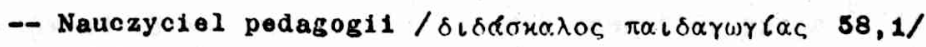


- Słowo Nauczajace /

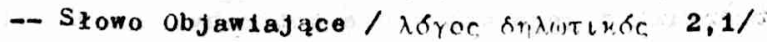

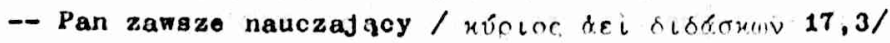

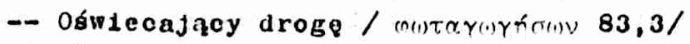

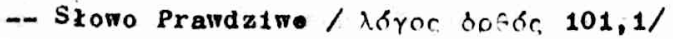

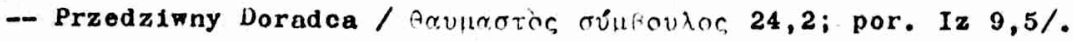

Idea donınują, nadrzędna welaoj 1 do wazystk1ch 1 nnych, jest 1dea Boga Zbaniciela, Boga miłujqoego człowieka, który litujac się nad nędza 1 słabościa swogo ludu wybawia go zo wszystkich nieszczęść 1 prowadzi do doskonałośc1 dajacej zycie wieczne. Zbawiente jest jednym wielkim dzlezen miłośc1 Chrystusa, lctóre, jak to juz wcześniej zauwazyz $\pi$. Volker ${ }^{30}$, obejıuje tak Wolelenie 1 higkę, jak 1 do dzís trwające Wychorante szeroko rozumiane ${ }^{31}$, jako prowadzenie Ludu Nowego do peznl zycia.

-- Chrystus Bóg - Zyole wybaw1a swój lud od śmierc1, dajac mu udziaz wwym Boskim zyciu;

-- Chrystus - Boski Lekarz wybawia swój lud z choroby grzechu;

-- Chrystus - Bóg, Pokarm prawdziwy, wybaria swój lud od glodu;

-- Chrystus - Bóg, Ojcioc, Matka, Wychowawoa, Trener wybawia sw6j lud od sieroctwa 1 niedorozwoju;

-- Chrystus Bosk1 Przewodnik, Pasterz 1 Król wybawla swóf lud od bezprawla 1 anarchil;

-- Chrystus - Bóg, Swiatło Prawdy, Boski Nauczyciel wybawia swóf lud od clemności błędu 1 niewiedzy.

Chrystus w wykładz1e I ksiegi "Pedagogan jost przede wszystkim Bogiem Zbawiajacym, zaspokajajacym wszystkie potrzeby ozłowleka. Teocentryzm /chrystocentryzm/ 1 swodscle rozumiany antropocentryzm egzystuja tu obok siebie. Z jodnej strony w centrum zaintere-

30 W. V8lker, Der wahro Gnostiker naoh Klomens Alexandrinus, Berlin 1952, 99: "Foht griechisch Paset Clemens Chriet1 Liebeswerk, das in dor Inkarnation begann, in dor Passion oinen Hohenpunkt errelchte und bis heute fortdauert, als eine brziehung auf".

31 Por. F.Draczkowsk1, Struktury setsantyczne wyrazu $\pi \alpha \iota \delta \varepsilon l \alpha$ w disiole Klemensa Áleksandryjskiego $\sum \tau \rho(1) \alpha \tau_{\varepsilon} \tau_{S}$, w: Z żagadnien 11teratury grock10J, Lublin 1978, 151. 
sowanla Klemensa jest człowlek 1 jego wszystkie potrzeby, z drugiej jednak strony tak samo wazne miejsce zajmuje Ten, który człowieka wyrywa ze wszystkich jego nieszczgsc 1 zaspokaja wszystkie jogo potrzeby. Ii zaleźnoścl od Punkcjl, jakie pełnl, nosi przeliczne 1miona; tylko w jeunym dziele Kleriensa wyllozono lch az sto czterdziośc1, a strescozaja się one wszystkie w linjeniu Boga Zbawiciela.

\section{Chrystus - Słowo Odw1eczne, Bóg 1 Pan}

Spécyficznym rysem chrystologil klemensa jest wyeksponowanio na plan plerwszy Syna Bozego, Słowa Odwlecznego oraz jego Punkcj1, jakie pełniz od stworzenia śwlata 1 nadal sprawuje. Członieozelstwo Chrystusa 1 . jego historyczna dzlałalnośc podozas pobytu na ziem1 potraktowana jest drugorzednie. Tendencja ta została zaumazona tak przez dawnych, Jak 1 wspóxczesnych badaczy toolog11 Aloksandryjezyka. Th. ilther twierdzi, ze Klemensa bardziej interesuje bóstwo Chrystusa, dlatego w relacjl do człowjeczeństwa Chrystusa pośw lęca ra o wicle wigcej ulejsca ${ }^{32}$. A.Brontes1 zaurazyz; ze Parłowa wizja Cirystusa, który stał slą oflarą, poniósł męke 1 śmieró za nas ludzi, v teologit klemensa sciodzi na drugi plan ${ }^{33}$.

Powyzsze tencencje Klemensa znajduja swoje odbicie womenklaturac I ksiegl "ledagoga". W trakcie narracjl termin Aoros - Słowo" powtarza siz az 127 razy. Drugle określente najozęściej uzywane to rzeczownik " kíplof Pan", wystepujzcy 105 razy. Obydwa terininy zdecydoranie eksponujz bústiro Chrystusa ${ }^{34}$. Imio "Chrystus", z ktorym w plerwszye rzg̨izie kojarzy sie Jezus Chrystus z Nazaretu, czlowiek, syn Mary1, występuje zaledwie 48 razy; Im1e "Jezus" Jeszcze mniej,

32 Th. illther, Die LAlblichkelt Christ nach Clemens von Alexandrien, "Theologische Quartalschxift" 108/1926/43: "Sein grosseres Intoresse aber gohyrt ... der Gotthe1t Christ1. So hat Clemens ohne sichtilche Bedenken Anschauungen vortragen konnen, in denen das Menschliche in Christus gegentiber dem Gottliohen vorkarzt exscheint".

33 A.Brontes1, dz.cyt. 603: "Il conoetto paolino d1 Cristo docausto per gli uomini o 1 conoetti della passione della morte passano In socoondo ordine".

34 Zob. J 1,1: "Na poczatku było Słowo / $\lambda 6 \gamma \circ \zeta /$ a Słowo było u Boga, 
bo tylko 22 razy; obydwa najczúciej w cytatach z listów św.Pawła. iV całej I ksiądze "Pedaroga" znajdujemy łącznie 563 określenia rzeczownikowe odnoszace 81 z do Syna Bożego, Jezusa Chrystusa. W'śród n1ch aż 417 określa wprost lub eksponuje wyraźnte Bóstwo Słowa Wcielonego, jak np.: Bóg, Słowo, Pan, Zbawca, Sędzia, Stwórca, Nładca, Fyohowawca. Stanowi to $75 \%$ wszystkich określeń rzeczownikowych. Pozostałe 146 terminów eksponuje przede wszystkin czlowieczeństwo lub w równym stopniu bústwo 1 czlowieczeństwo Chrystusa, jak np.: Człowlek, Jezus, Chrystus, Sługa, of lara, Laraneic Bozy, Potonek Dz1ewicy. Zatem aż $3 / 4$ mszystkich określeń eksponujo boskosc 1 Bost:o Cnrystusa, a tylko $1 / 4$ zwraca uwage na jego czrowieczenstwo. Ta wymowa liczb jest wielce znamenna, bo ziaje sie potwierdzac spostrzezenta wyżej cytowanych autorów. Chrystus I księgl "Pedagoga", to przede wszystkim Bóg, Syn Boży, Odwieczne Słowo Ojca, Bosk 1 Wychowawca 1 Nauczyciel, Stiórca 1 Włauca. Klenens nie zapouina bynajmniej o człowleczeństwie Chrystusa, pierwszoplanowo jedrak eksponuje Jego Bóstwo. Gdyby w oparciu o nomenkliturę chrystologiczn: I ks1egi "Pedagoga" skreślić portret Chrystusa, to relacja bóstwa do człowieczeństwa wyrażałaby sie stosunkiea 3 : 1 . Obraz Clirystusa Słowa Odwlecznego, Boga 1 Pana zdecyuowante douinuje nad portacia Jezusa z Nazaretu, Syna Mary1.

\section{Chrystus Boski Wychowawca, wiłujacy człowieka}

W poprzednim paragrafie starano sie odpowiedzieć na pytanie, kim przede wszystkim jest Chrystus w świetle nomenklatury I kslęgi "Pedagoga". Obecnie nalezałoby zapytać, jak przedstawia sle charakterystyka Chrystusa Boga - Człowleka w ślietle określeń przymiotnikowych wymienionego dzieła Klemensa. Inaczej mówiac chodzi o pierwszorzędne ceohy wyróżnające Boskiego zbawiciela v na:racji Aleksan-

1 Bogiem było Słowo". Wyraz uv́los odnosi Klemens zarówno do Boga 0jca jak 1 Syna Bożego. Tylko dokłalne badanie kontekstu pozwala określić kogo $z$ dwu osób Boskioh na Klemens na myśli. 
dryjczyisa. Najezęstsza przydaw'sz odioszona do Chrystusa jest przymiot-

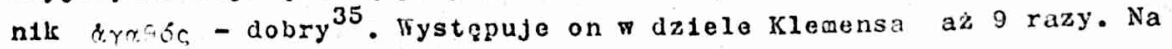
uwagz zaszuguje fakt, ze omawlana przydawsa az 4 razy łaczy sjaz z rze-

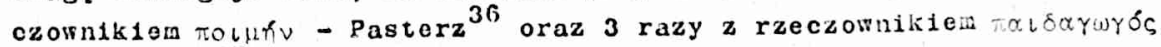
- wychowarca ${ }^{37}$. Farto uśw1ajonie subic, ze toriain $\pi \alpha \iota \delta \alpha \gamma \omega \gamma b ́$, wystepujacy w balanym dziele klemensa 72 razy, plasuje sie na trzecim miejscu, po rzoczownlkach $\delta_{\gamma} 061$ kíplos. Trudno zresztzoczekiwać, żeby było 1naczoj, skoro omawlany termin stanowi tytuł badanego dzieła. Natomiast tornin roluro - Pasterz wystepujac w I księze "Pedagoga" 11 razy lokuje siq doplero na ósmym alejscu. Majio wi zc na uwadze sana czestotlíwośc nystẹowanla rzeczownikón I przyiniotników odnoszonych do Chrystusa, mozna by powiedzloć, ze obok Chrystusa. Słowa Odwiocznego, Boga 1 Pana, Jaw1 sie na druglm miejscu obraz Chrystusa dobrego Vychowawcy, Chrystusa dobrego Pasterza. W trakcle lektury dzieła Klemensa mozna zauwazyć, ze funkcje Pasterza przejmuje czesto Wychowawca 1 odwrotnie. Jeśl1 lud Bozy przyrównywany jest do owczarni, jawi siq obraz Pasterza; jeśli do dzlec1 - przywokymana jest postać Wychowawcy. IV sumie obydia te obrazy nakładaj 818 na sieble /por. 84,1/. Docinacje jednak przejmuje obraz Pedagoga. W Nowym Testamencie Chrystus nigdzie nie jest określony jako $\pi r \downarrow \delta \alpha \gamma \omega \gamma \sigma_{c}$ - Wychowarica, natomiast często nazywany jest pasterzom ${ }^{38}$. Hyc mozo wisc klonens identyfikujac Wychowawce z Pasterzem chcial niejako zolizyc ao biolil wprowadzony

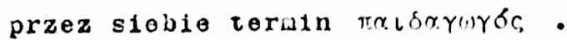

Lobry wychowawca, nazwany jest tez przez Klenensa "najlepszym

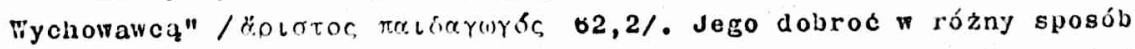
1 W róznych okolicznosciach s18 przejawia. rakt, ze chrystus oadaz za nas życio jest najlepszyn aowodem jego dobroci: "do tego stopnia by dobry, zo umarł za nas" /85,2/. Dobrod moze przejawiać się jako hojnośc. Klecens zauwaza, ze Chrystus "sam wyznaje, że jest dobrym pasterzem: jest hojny, guyz daje za nas to, 00 ma najwiekszego, swoje zycle" /85,2/. Dobrob moze sie przejawiao wostawie słuzebnej. Dobry słuzy Innym. Zuaniem Klemensa "Takim jest nasz Pedagog, rzoozywib́cie jest dobry. Nie przybyłein - mówi - aby mi ałuzono, lecz aby słuzyó.

35 Por. Lk 18,19: "Czemu nazywasz Mnie dobrym? N1kt nie jest dobry, ty lko sam Bóg".

36 I Paed 37,$2 ; 84,2 ; 85,2 ; 97,3$.

37 Tanze 6,$2 ; 66,2 ; 98,2$.

$38 \mathrm{~J} 10,9.11 .16 ; 1 \mathrm{P} 2,35 ; 1$ P 5,4; Hbr 13,20. 
Dlatego w Ewangel11 ukazany jest jako utrudzony, bowiein poświęca sie dla nas 1 , da swoje zycie na okup za wielu"39. Dobroó Chrystusa przejawia sie w caloj Jego postawio 1 charakterzo. Jest On łagodny

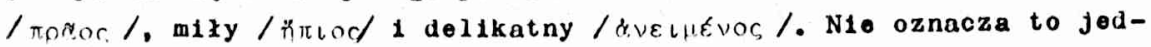
nak, że stosuje źle rozumianz pobłażliwośc. Jako dobry wychowawca szuka prawdziwego dobra swotoh wychowanków. "Charakter Jego, zo vzgledu na dobro, nle jest anl zbyt surowy, ani zbyt zagodny" /98, $1 /$. Jeśl trzeba potrafi równiez ganlé 1 zajać. Klemens zaznacza jednak, te "Pan nie gani z nienawiśc1 ludzi, gdyz sam cierpiaz za nas. Pedagog, który jest bardzo dobry, rozpoczyna nagane umiejętie od złorzeczenia uzywajao ostrych słów bicza, aby rozbudzis otępiałość umysłu, to znowu zmieniwszy metode ustzuje osiłgnás cel poprzez zachęt बి" $/ 66,2 /$.

Dlatego tez dobroó w Chrystusie harmonifnie łączy sie ze sprawlodliwośc1q. Przydawk $\delta(x \alpha \iota \cap c$ - sprawiedliwy jest 9 razy odnoszo-

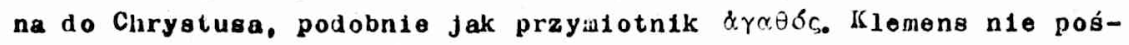
wieca wiяcej miejsoa na ukazanie tej cechy. Wyprowadza ja gzównio z Boskości Chrystusa. Sprawledliwość należy do 1stoty Boga. Zdantem Klemonsa "eprawiedliwosé 1 dobro to jest oczywiście Bóg" $/ 88,1 /$. W okresientach przymiotnikowych Boskośc Chrystusa jest ozgsto eksponowana. Az 5 razy przymlotnik $\partial \varepsilon \tau \circ \zeta$ - boski odnoszony jest do Chrystusa. Obok zkozenla "dobry Wyohowawca", które, Jak wyzej powledzla-

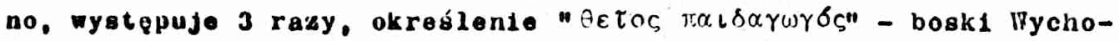
wawca wystgpuje 2 razy $/ 81,1 ; 97,3 /$. Boskośc Chrystusa eksponuja od-

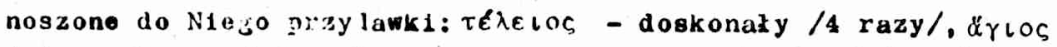

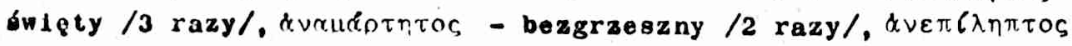

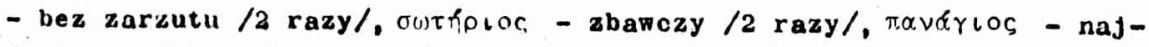

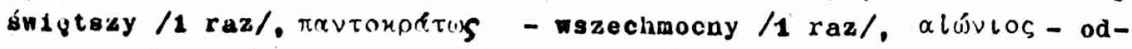
wloczny $/ 1$ raz/. Chrystus jest doskonatym Pedagoglen dziogk swemu Bústwu. Bowlem boska Jago nutura jest głównym źródzem, z którego wyplywdj t trzy glówne cechy doskonalego fiychowawcy. Oto Jak Klemens oharakterycuje postus dobrego Viychowawoy: "Godny wiary jest bosk1 Pedagog ozdoblony trzema najplekniejozymi przymlotami: wiedza, zyczliwościa 1 autorytetem. Wiedza, poniemaz jest On Waqdrościa 0jca: "Caka iagdrośd od Boga pochodizi, jest a Nim la wiek1". Autorytetem, gdyz jest Bo-

39 Zob. Mt 20,$28 ; \mathrm{Kpz} 26,21,23,27$. 
giero 1 Stwórcą: "Tszystko przez Niego się stało, a bez Niego nic s1ę nie stało". Zyczliwośclą, bowiem sam wydał siebie na oflare za nas: "Dobry pasterz daje zycle swoje za owce" 1 on rzeczywíscie jo złozył"40. W powyżzym cytacio klomens wyraźnie nazywa Chrystusa Bogiem 1 stwórcą.

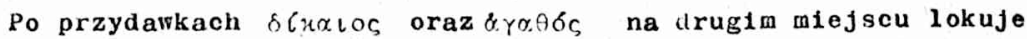

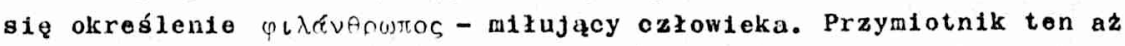
6 razy został odniesiony do Chrystusa. Rzeoz znamienna, wystepuje

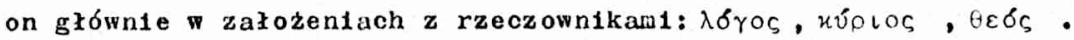
Tylko jeden raz łączy sie z terminem $\pi 0 \iota \mu r \nu$ - pasterz $/ 85,2 /$. W ten sposób Klemens ponownie akcentuje Bóstwo Chrystusa, który z miłośc1 do nas ludzi, zapragną by 6 jednym z nas. Według słów Klenensa Chrystus "jest bardzo zyczliwy / $\mu \varepsilon \gamma \alpha \lambda \omega \varphi \varepsilon \lambda$ r $/ 1$ mlłuje człowleka

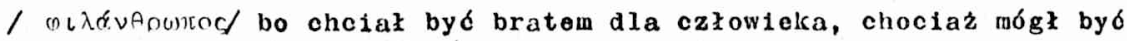
Panem" /85,2/. Przejawem miłości Boga - Człowieka do ludzi są wszystkie zableg1. wychowawcze, jakie stosuje on wobeo ludu zbaw10nego. "Będąc jednocześnte Pedagogiem I Sędziaz sądzi tych, którzy są mu nioposłuszni; miłujący ludzi / przemlloza toh grzechów, lecz doświadcza lch, by się nawrócili" /58,2/. Dalszym dowodem, że Bosk1 Logos kocha człowieka jest clagła pomoc, Jaka mu śwladczy, troska 1 opleka, Jalca go otacza. Tedług słów

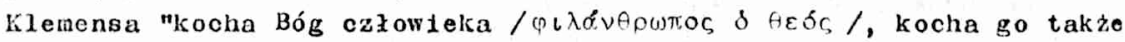

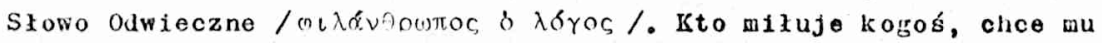
pomagać, a ten, kto ponaga, jest z pewnością lepszy od tego, kto nio pomaga; nie ma żadnej rzeczy lepszej od dobra, dobro zatem pomaga. Dobrem zaś jest Bóg, a więc Bóg pomaga. Dobro, o lle jest dobrem, nic innego nie czyni, Jak tylko ponaga, a więo Bóg pomaga zawsze. /.../ I pomaganie dobrowolne nie jest niczyn innym jak troszczenien sle o człowieka. Zatem Bóg troszczy sle o człowieka i opiekuje sie nim. Ujawnia to w diałaniu, nauczajac go poprzoz swego Syna, który jest prawdzlwym wspólntkiem mikości Bozej ku ludżiom / tof GEof

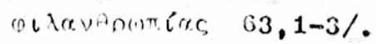

IV śwletle określen przymlotnikowych I ksiegi "Pedajosa" Chrystus jawi sie nam jako Boski Wychowawca, który harionijnio zączy w sobie cochy boskie 1 ludzkie. Będąc prawdziwym bogiem 1

40 Paed I 97,3; Puton 125; zub. Syr 1,1;J 1,$3 ; 10,11$. 
prawdziwym człowleklem, z jednej strony okresiany jest jako bosk1, doskonały, swięly, dezgrzeszny, bez zarzutu, zbawczy, najświetszy, wszechmocny - z drugioj zaś jako przeznaczony na cierpienta, utrudzony, zmezcony, skuzqcy czkowlekow1. Jako doskonały Podagog laczy w soble cechy pozorn1e przeciwstawne: będac dobrym nie przeotaje być sprawledliwym; jest kagodny, mizy 1 delikatny, ale jak traoba potraf1 byc nymagajacy 1 surowy. Plerwszoplanowo jednak ukazuje s18 Jako Bosk1 Wychowawca, pomagajacy człowlekow1, troszczacy sie o jogo zbawiente, oplekująoy ble ludźnt, dobry 1 zyczliwy B6g, mizujacy ozłonieka.

\section{z a k o n o z n 1 .}

Jak zaznaczono na poczatku ograniozento badań do jednoj tylko kslegl jednego dzieka Klemensa nio pozwala na snucio zbyt daloko Idacyoh konkluzj1 na temat jego chrystologi1. $Z$ druglej jednak strony badania szczegółowe, nawet niewielkiego wycinka twórczości, rokuja nadzieje na wykrycle pewnyoh linil wiodących, jakie dominuja w oakej toologil Aleksandryjozyka. Prezentowany zatem powyzej materiaz upowaznia do postawienia wniosków, które chca byó czymó wiecej, niz zwykkymi hipotezami roboczymi.

Plorwaza konkluzja, Jaka sie nasuwa, dotycay postawionej przez Quastena tezy o logocentozmio Klemensa Aloksandryjskiego. Mozna by 180 odpowiedzlec, to $w$ św1etle onomastyk1 I ksiegi dagogan teza powyzeza byzaby trudna do utrzymania. Preqdzej nalezałoby cóvić o "soterlocentryzmien naszogo autora. Cała bow1em przeogromna nomenklatura ohrystologiozna na pierwszy plan eksponuje Chrystusa Boga zbawiająogo wjeciu dynamicznym. N1e moze ujśó uwag1 ogromne bogactwo lmion 1 określeń, które klemens odnosi do Chrystusa. Nalozy tez dodad, te jest to onomastyka b1bl1jna. W llozbach waglednych na 87 okrésleá rzeczownlkowych 48 spotykamy B1b211; 39 jest poza biblijnyoh. Zatem 55\% tu okroblenia blblijne. Procent ten bedzie o wiele wyzszy, jeśli zsumujomy wszyatk1e określenta rzeczowulkowe. Jak wepomniano juz wczesintej, Jest lch lacznie 563. Z tej liozby at 433 to okresie-

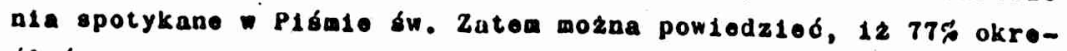
iloif rzoczownikowyoh zuozerpnal klomene z Biblil. Zreszla to na- 
stawionie na Blblig je:t charakterystyczne dla prawle wszystkioh ojców Koścloła, dla Klemensa zaś w szczególnośc1 ${ }^{41}$. W chrystolog11 Klomensa notujemy tendeneje do wleloaspektowego, w mare wszechstronnego, ujecla postaci Boga - Człowleka, który wybawla swó lud ze wszystkich nioszczęść 1 prowadzi go do doskonałośc1 dajacej zycle wieczne, Chrystusa Boga - Życie, który wybawia swój lud od ́́mierci, Chrystusa Boskiego Lekarza, wybawlającego z choroby grzechu, Chrystusa Boga, który jest Pokarmem życia 1 wybawia lud swój od głodu, Chrystusa, który jest ojcem, Matka, Tronerem, Wyohowawca, Przewodnikiem, Pasterzem, Królew, Swlutłein, Prawda i Nauczyolelem. Przy tym wszystkim postavionle akcontu na boskośc1 1 odwiecznośc1, poszerza 1 ubogaca obraz Synn Bozego, przeciwieństw1e do współozesnych tendenojl ekssponujacych postac historyczna Jezusa Chrystusa z Nazarotu, któro raczej Ja zubozaja 1 pomniojszaja, nlo mówiąc juz o tym, ze vonsekwonoji dalszej prowadza do swolstej formy wspófczesnego arianizmu. Obraz Chrystusa Boskiego wychowawoy, nikujacogo człowloka, Syna Bozogo, który "słusznto nazywa sie Podagogiem, gdyz prowadz1 nas, dz1001 do zbaw1enia" $/ 53,3 /$, kompletuje przedstawiona przez Klemensa Aleksandryjskiogo wizje Chrystusa Boga Zbawiajacogo. Niniejsze roziazania mozna by zakończyó rofleksją o aktualnośc1 wyżej zarysowanego szkicu chrystolog11. N te można przeciez przeczyć faktowi, zo Piotr naszych ozasón, Jan Pawol II u progu swogo pontyfikatu w onoykl100 "Redemptor hominio" ukazał ludzkości postać Chrystusa, Boga, który jest Zbaw1o1elem ozłow1eka.

kø. Frano18zok Draczkowsk1 - Lublin

11 A. Quacquaroll1, Scuola o cultura dol primi secoli oristiani, Broscla 1974, 14: "... wa la sua /d1 clowento/ vora cormazione, o ome quello di tutti i Padri della Chiesa, b biblioa. Il filo oonduttore che lo guida è la Sacra Sorittura". Por. F.Drifozkowski, Dorartościowanie kultury inteloktualnej przez klowensa dleksandryjsklego jako rezultatu poleciki antyheretyckloj, "stuuli polplińskle" 10/1975/ - 197-199 paragraf pt. "Postulat dowartościowania roll Pisina siviętogo: poprawnoj ogzegozy". 


\section{ABIISS DEI CiIRISTOLOGIE VON KLEMENS VON ALEXANDRIEN}

IMI LICHTE DER ONUMASTIK DLS ERSTEN BUCALS DES "PADAGUGEN"

\section{/Zus ammeneassung/}

Im ersten Buch des "Padagogen" treffen wir 87 verschiedene Substantiv- und 53 Adjekt1vbezelchnungen, die auf die Person von Jesus Christus bezogen sind. In den melsten Fyllen stamen diese Bezelchnungen aus der Bibel. Die Leitlinie und Achse, um die herum alle dieso Bezelchnungen grupplert werden kbnnen, lst die Ideo des erlosenden Gottes, des den Mensohen liebenden Gottes, der sich uber die Not und Schwachielt seines Volkes erbarmt und es von allem Ungleck erlost und zur Volikommenhelt fuhrt, die wirkliches Leben schenkt. Die Idee der Erlosung wird hler sehr weit verstanden. Christus als Gott und Leben erlost sein Volk vom Tude uni is $10 t$ inu anveli an sulsem gotllichen leven; alo gotillcher arzt eribst or sein Volx von der arankneit aer sunde; als wirkliene Nahrung erlost er sein volk vom Iunger; als Vater, Mutior, Erzieher und Irainer rettet or sein Volk vor Verwalsung und Zurtokgebliebenhe1t; als Fuhrer, H1rt und Kontg schatzt or sein Volk vor Verirrung, Unrecht und Anarchie; Christus als cott, Licht der liahrhelt und gottlicher Lehrer erlost sein Volk von der Finsternis des Irrtums und der Unwissenheit. J.Quastens These von Klemens'Logozentrismus wire im Lichte der Onomastik des 1. Buches des "Pldagogen" nur schwer aufrechtzuerhalten. Man musste eher vom "Soteriozentrismus" unseres Autors sprechen. Das Bild Christi als des ewigen Wortes, Gottes und Herrn domplert entschieden uber der Gestalt des Jesus Christus von Nazareth, des Sohnes der diarla. Im Lichte der Adjektivbezelchnungen erscheint Christus in erster Linte als gottlicher Erzieher, der gottliche und menschliche ztige harmonisch in $81 \mathrm{ch}$ verelnt; or ist volikommen, heilig, studios, heilsam, allmalchtig, zum Leiden bestimint, beladen, gemar jert und dem Nonschen dienend; er erscieint als guter und freudilicher Gott, der den Lenschen liebt, thm hilft und sich um seino Erlosung sorgt. 